\title{
Endometriosis related sex steroid hormones, hypothalamic pituitary gonadal axis hormones and related animal modeling: A comprehensive review of published articles and endometriosis induction methods from 2010 to 2021 with scoring based approach
}

\author{
Aria Salehpour ( $\square$ ariasalehpour98@gmail.com ) \\ Bushehr University of Medical Sciences https://orcid.org/0000-0002-6592-5202 \\ Afshin Zare \\ Bushehr University of Medical Sciences \\ Arezoo Khoradmehr \\ Bushehr University of Medical Sciences \\ Mahdi Mahdipour \\ Tabriz University of Medical Sciences https://orcid.org/0000-0002-2729-4593 \\ Amin Tamadon \\ Bushehr University of Medical Sciences https://orcid.org/0000-0002-0222-3035
}

Research Article

Keywords: Sex steroid hormones, estrogen, progesterone, endometriosis, animal model

Posted Date: December 22nd, 2021

DOI: https://doi.org/10.21203/rs.3.rs-1137695/v1

License: (c) (i) This work is licensed under a Creative Commons Attribution 4.0 International License. Read Full License 


\section{Abstract}

Endometriosis is an enigmatic gynecological disease initiated by the ectopic growth of endometrial tissue and causes critical symptoms such as chronic pelvic pain, cyclic menstrual pain, subfertility or infertility. Considering extensive investigations for explaining the underlying pathophysiology of endometriosis, origin and distinctive processes which lead to endometritic state are not completely understood. In this comprehensive review, studies published from 2010 to 2021 are reviewed in order to provide a bright insight through the applications of translational animal models and endometriosis induction methods for evaluation of endometriosis pathogenesis and treatment. We provided method based inclusion criteria and reviewed all hormone-based studies with concentration on animal models. Additionally, studies with novel induction methods and approaches are categorized separately and analyzed by a novel scoring table for suitability of further investigations. Eventually, our scoring system suggested that the best-evaluated animal model for hormone related endometriosis studies is an "unopposed estrogenicity baboon model of endometriosis".

\section{Background}

Endometriosis is distinguished from other diseases by benign presence of functional endometrial tissue outside the uterus. Its symptoms include chronic pelvic and cyclic menstrual pain and infertility. The prevalence in women is generally considered to be 1-5\% (1). Although different mechanisms of endometriosis generation have been studied thoroughly, the processes which lead to development and maintenance of endometriotic state have not been completely understood yet. The development of new surgical methods and medications for the prevention, elimination of disease or its recurrence, necessitate defining the pathophysiologic mechanism.

Since endometriosis is a multifactorial disease and these risk factors cannot exclude each other for the explanation of pathophysiology of this disease, various models and approaches were proposed (2). Widely accepted pathophysiological aspects can be classified as inflammation (3), immunological factors (4), environmental factors (5), genetics (6), pain (7), infertility (8) and hormones which is explained extensively in the following text. While several theories are described in each category, it is not certain which one is the primary reason for the occurrence of endometriosis. Still, one of the main theories for the ectopic formation of endometrial tissue in the peritoneal cavity is considered to be old "retrograde menstruation" (9)!

Estrogen-dependency of endometriosis has been well documented in copious studies (10) and drugs that reduce or suppress sex steroid production in ovaries for endometriosis treatment (11) or relief of its symptoms such as pain (12) have been proposed. One of the key modulators in endometriosis pathogenesis is increasing of local production of estrogen (13). Many effects of sex steroids are mediated by their actions at their nuclear receptors, while growing evidences have shown that many of these effects may not be receptor dependent (14). Due to latency of disease diagnosis and occurred progression of the disease at the time of presentation at clinic, it is not possible to perform experiments with the aim of detection of predisposing factors, which are related to synthesis or play a role in sex steroid effects in endometriosis. Due to ethical considerations, controlled experiments such as disease progression monitoring by repeated laparoscopies are limited. Therefore, animal models of endometriosis can be the solution to perform extensive research on sex steroid effects and their related mechanisms of ectopic endometrial tissue or cells adherence, invasion and vascular establishment, development of new approaches for investigating the initial occurrence or recurrence prevention or even treatment of lesions.

Since now, the closest models to humans for the evaluation of endometriosis are non-human primates. Because of their high cost and handling limitation in the use of these models, small laboratory animals were used as alternative models of endometriosis. This literature review is aimed to provide comprehensive insight through hormone related animal models of endometriosis and compare different induction methods of endometriosis, advantages disadvantages, and their application for evaluation of sex steroid hormones effects in pathogenesis of endometriosis. Additionally, a summary of all published studies is provided and a novel scoring table is designed to attain a full acquaintance over most important aspects of available animal models.

\section{Materials And Methods}

We used PubMed/Medline database as the source for finding sex hormone related endometriosis researches. All included studies were published form 2010 to 2021. We used Mendeley Desktop application for screening the results and following search query was utilized in order to discover all related papers. Mentioned search query resulted 158 related papers in our desired time interval. "endometriosis" [Title/Abstract] AND ("animal"[Title/Abstract] OR "model"[Title/Abstract]) AND ("hormone"[Title/Abstract] OR "sex"[Title/Abstract] OR "steroid"[Title/Abstract]).

\section{Inclusion And Exclusion Strategies}


We included studies that were published between 2010 to early 2021, which have proposed an endometriosis induction method in animals as the first criteria. An assessment of sex steroid hormones (SSH) or Hypothalamic pituitary gonadal (HPG) axis hormones had to be met (receptors or concentration assessment) as the second inclusion criteria. We reviewed all the studies that met our circumstances in section 4 and articles that represented a novel induction method were classified in segment 5 separately. The more popular older approaches that section 4 studies utilized were also reviewed and explained separately.

We considered sex hormones by terms of gonadal steroid hormones, testosterone, androgens, estradiol, estriol, estrone, estetrol, estrogens, phytoestrogens, progesterone, progestogen and progestins as SSH (15). Furthermore, luteinizing hormone (LH), follicle-stimulating hormone $(\mathrm{FSH})$, Gonadotropin-releasing hormone $(\mathrm{GnRH})$ and melatonin were considered as HPG hormones. We excluded non-English articles and review articles result. We also did not consider studies which have utilized steroid supplementation while inducing endometriosis in murine models of endometriosis as a hormone related study.

\section{Hormone Based Endometriosis Studies Utilizing Previous Induction Methods}

This section has included all the sex steroid hormone related studies of endometriosis and provides an insight through assessed therapeutics for endometriosis using animal models comprehensively. Additionally, section 4 provides targets of interest in endometriotic state, mechanisms and potential drugs which ameliorate the situation significantly. In the end of this section, a review of more frequently cited induction methods is prepared to provide a contrast between older methods and newer methods generally.

\subsection{Sex steroid hormones related articles}

\subsubsection{Estrogen and its receptors role in endometriosis}

The levels of estrogen, regulations of estrogen receptors (ERs) and involved pathways in endometriotic state is considerable. In this section, all related studies based on our inclusion criteria are presented and discussed separately to provide an overview over contribution of animal models to this field in a detailed way.

\subsubsection{Puerarin and endometriosis}

Blocking the effects of estrogen receptors can be used as a potent strategy for suppressing the lesion development. For instance, hERßal (estrogen $\beta$ (Er $\beta$ ) agonists) and chemical estrogen blocker or modulator are used in-vivo and can be easily tested in this model. It is shown that puerarin, a phytoestrogen with a weak estrogenic effect, could suppress the endometriosis development in the rat model by binding to estrogen receptors. Puerarin was shown to ameliorate disease state by inhibition of P450arom expression while having no effects on estradiol receptor-a expression. These resulted reduced serum estrogen levels as well as reduced endometriotic tissue weight (16).

\subsubsection{Xenografting of human tissue supplemented with estrogen and progesterone}

Coudyzer et al. proposed an endometriosis model of mice in order to study self-renewal of endometrial tissue after menstruation. They subjected mice to human endometrial functionalis fragments grafting and supplemented them with of $17 \beta$-estradiol and progesterone pellets for 21 days. Four days after removal of pellets, $17 \beta$-estradiol pellets were utilized again to resemble early proliferative phase. They assessed estrogen receptor ER-a expression in the graft and noticed that the majority of cells in the stroma and glands were immunolabeled positively. They also noticed that hormone withdrawal led to rapid apoptosis and decrease in graft volume. The interesting finding was resistance of the graft volume to grow after reinsertion of estradiol pellet, despite detecting mitosis in the target tissue. (17).

\subsubsection{Cisplatin and letrozole effect on rat model of endometriosis}

Cisplatin (Cis-Diaminedichloroplatinum, CDDP) is the preferred drug in the treatment of endometriotic adenocarcinoma cancers (18). CDDP's anti-neoplastic activity comes from its binding ability to DNA molecules in target cells to induce DNA cross-links (18). These findings have made this drug a recommendable treatment for endometriosis (19).

It has been shown that Aromatase's enzyme is aberrantly expressed in ectopic and eutopic tissue in patients suffering from endometriosis (20). Considering that letrozole is an aromatase inhibitor which can suppress local and systematical estrogen production (21), it is hypothesized this drug could be probably used for treatment of endometriosis. In order to address that, a rat model of endometriosis was proposed. Cisplatin and letrozole both showed similar regression of the implants in the rat model while their effects on angiogenesis, protein expression and sex steroid hormones were not consistent (22). 


\subsubsection{Telocytes damage in endometriosis-affected rat oviduct and potential impact on fertility}

Telocytes are widely available in various tissues of human body (23) and are also identified in endometrium tissue of rat (24). It has been revealed that telocytes population decline in women with endometriosis and tubal ectopic pregnancy (25). Auto-transplantation induction method was implemented to investigate telocytes morphology in rat model of endometriosis. Rats with endometriosis conditions shown to exhibit tissue degeneration, substantial decrease or loss of telocytes with elevated levels of inducible nitric oxide synthase (iNOS), Cyclooxygenase-2 (COX-2), lipid peroxide (LPO) and estradiol, as an inflammation indicators (26).

\subsubsection{Niclosamide and endometriosis}

It is documented that niclosamide disrupts multiple signaling pathways of STAT3 signaling in a variety of cancer models (27). Niclosamide could reduce the size of endometriotic implants in a mouse model of endometriosis by effecting inflammatory pathways. Niclosamide did not affect steroid hormone receptors in the endometriotic implants either, indicating that the drug does not disrupt ovarian function (28).

\subsubsection{Neuroangiogenesis and endometriosis}

Ectopic endometrial tissues have een revealed to contain nerve fibers in addition to excessive formation of blood vessels (29). Co-existence of nerve and vessel leads to known common chronic pain of endometriosis. Neuroangiogenesis is also known to be adjusted by axonal guidance proteins like SLIT (30).Greaves et al. showed that mRNA expression encoded by SLIT3 gene was significantly higher in ectopic endometrial tissue than normal peritoneum, suggesting probable SLIT3 role in vessel-nerve cell interaction. Additionally, they indicated that in response to activation of ERa, SLIT3 is secreted by neurons, increasing angiogenesis (31).

\subsubsection{Macrophage-nerve cross talk and endometriosis}

In a study by Greaves et al. a role for Estradiol in stimulating macrophage-nerve interactions using in-vitro and in-vivo models was demonstrated. They firstly showed macrophages and nerve fibers to be adjacent to peritoneal endometriosis lesions. Further, it was noted that ER $\beta$ was expressed more than ERa in endometriosis local macrophages providing evidence that endometriosis can be considered as an estrogen-dependent neuroinflammatory disorder (32).

\subsubsection{Simvastatin and endometriosis}

Statins are shown to prohibit in-vitro proliferation of eutopic and ectopic endometrial stromal tissues (33) and can ameliorate endometriotic lesions in murine models (34). Simvastatin as a statin drug was evaluated by Taylor et al. in auto-transplantation baboon model of endometriosis. A daily dose of $20 \mathrm{mg}$ simvastatin was shown to reduce various lesion size significantly. Additionally, estrogen receptors expression (Er1 and Er2) were evaluated. The treatment significantly suppressed the expression levels of ER2 in black lesions and upregulated the expression of ER1 in red lesions, supporting the suggestion that simvastatin could be effective by inhibition of mevalonate pathway, a growth reduction of endometrial lesions and ameliorating inflammation state. Furthermore, simvastatin significantly reduced the expression of neopterin, a marker of inflammation, oxidative stress, and immune system activation (35).

\subsubsection{Chloroindazole (CLI), oxabicycloheptene sulfonate (OBHS) and endometriosis}

$\mathrm{CLI}$ and OBHS are ER ligands with high selectivity for ER $\beta$ and ERa respectively (36, 37). Zhao et al assessed the efficacy of these potent ligands for endometriosis treatment in aERKO and aERKO mice mouse models. They showed that CLI or OBHS could considerably reduce cell proliferation in ectopic lesion, vascularization and cyst formation and also ameliorate inflammation. There was no correlation between ERa deficiency an lesion growth, whilst ER $\beta$ depletion in recipient animals caused reduction of ectopic lesions size (38).

\subsubsection{Progesterone family and its receptor role in endometriosis}

One of the specifications of endometriosis is progesterone resistance which was coined in 2000 by (39). There are multiple factors which support progesterone resistance like MicroRNAs (40), genetics (41), Mesenchymal stem cells (42), inflammation (43) and so on. The contribution of animal models to assess mechanisms underlying progesterone resistance and assessing the efficacy of potential drugs is presented in the following section:

\subsubsection{Levonorgestrel loaded microspheres for the treatment of endometriosis}


Levonorgestrel is a member of progestogen medications family which is utilized as a means of pregnancy control. Yuan et al. used microspheres loaded with levonorgestrel to target ectopic lesions in an endometriosis rabbit model and avoiding side effects while attaining more efficacy. The proposed drug delivery did not provoke any side effects, therefore it was proposed as an alternative therapy (44). In another study, intra-cystic injection of levonorgestrel-loaded polylactic acid microspheres in rat had long-term effectiveness via downregulation of estrogen receptors in epithelium and stroma and Pr in the stroma of endometriotic tissues (45).

\subsubsection{Nomegestrol acetate and endometriosis}

Nomegestrol acetate is categorized as new progestins (46) and reveals a high selectivity for $\operatorname{Pr}(47)$ and shows anti-estrogenic profile on the endometrium (48). Zhang, Zhu, et al. benefited this principles and proposed a rat model of endometriosis in order to assess the potential efficacy. In order to amplify the results, they also used biodegradable microspheres as drug delivery approach to delay drug action. Treatment showed mitigation of ectopic lesions volume and decreased serum levels of progesterone, estradiol and Era while not effecting Pr expression level and vascular endometrial growth factor receptor 2 (49).

\subsubsection{Multi hormone based studies and endometriosis}

This sectioned was proposed to review estrogen and progesterone family related studies simultaneously. The utilization of animal models in revealing the effects of medications or pathophysiology of endometriosis is noticeable and all published studies are classified and presented as follows:

\subsubsection{Dysregulations of steroid estrogen receptors and endometriosis}

Estrogen receptors (50) and progesterone receptors (39) play a key role in development of endometriosis. Also G protein-coupled estrogen receptor 1 (gper1) are revealed to be upregulated in ectopic lesions. Mishra et al. utilized a mouse model of endometriosis to assess dysregulations of aforementioned receptors simultaneously. As a result, the level of ERa showed a reduction in expression while ER $\beta$ was elevated in ectopic grafts. Gper1 and PR mRNA expression was decreased in a time specific manner (51).

\subsubsection{Endometrial expression of steroidogenic factor 1 promotes cystic glandular morphogenesis}

In a study by Vasquez et al. expression of steroidogenic factor 1 (SF1) subfamily in endometriosis was thoroughly investigated. This family is responsible for regulating the expression of the steroidogenic genes within the ovary. Considering the fact that the ovarian tissue is the main site of steroid synthesis via the conversion of cholesterol to estrogen, the levels of progesterone, estradiol in serum and the expression of sex hormone receptors such as Pgr and ER1 and fertilization status in a mouse model of endometriosis were evaluated. The study revealed that SF1 is directly related to the growth of ectopic endometrial lesion, absence of decidua response and infertility. So that expression of SF1 was followed by a decrease of PGR levels in the epithelial section of the graft but ESR1 levels was not affected. They also related the yielded infertility as a result of PGR dysregulation (52).

\subsubsection{Niclosamide as a potential nonsteroidal therapy for endometriosis}

Prather et al. evaluated the effect of niclosamide as an inhibitor of endometriosis progression by blocking NF-kB, STAT3, and WNT signaling pathways. They further evaluated angiogenesis marker CD31, ER1 and PGR expression as well as the fertility status. Niclosamide could avoid implant growth considerably by decreasing cell proliferation. However, no significant differences of CD31 expression as well as fertility status were observed whereas epithelial and stromal ER1 and PGR expressions were not altered after administration of niclosamide indicating that it does not affect systemic estrogen function (Prather et al. 2016).

\subsubsection{C-Jun NH2-terminal kinase (JNK) inhibitor (JNKI) bentamapimod and endometriosis}

In parallel study with Palmer et al., (53) used a model of baboon endometriosis to assess whether JNKI solely or with medroxyprogesterone acetate (MPA) supplementation is effective for a more similar translational model to human. Treatment with JNKI solely and JNKI plus PMA, or cetrorelix resulted in decreased ectopic lesions. After treatments, FSH, LH and progesterone levels remained unchanged but estrogen levels were significantly changed (54).

\subsubsection{High-fat diet (HFD) promotion of endometriosis in an immunocompetent mouse model}

Polyunsaturated fatty acids (3-PUFA) levels influence immune, angiogenic, and proliferative factors implicated in the early establishment of endometriosis (55). High body mass index (BMI) is correlated with endometrial cancer occurrence (56) and high adiposity and 
endometriosis are closely correlated (57). In a study, Heard et al. examined the effect of high-fat diet ( $45 \%$ fat kcal) on mouse model of endometriosis. Klf9 WT mice were used as recipients of endometrial fragments from Klf9 null mice (donors). They assessed the correlation thoroughly by using an immunocompetent mouse model of endometriosis. A high-fat diet favored number of endometriotic lesions, higher proliferation and lower apoptotic status and a difference in differ in steroid hormone receptor expression. So that HFD-fed recipients had lower levels of total Pr and Esr1 but no differences for Esr2 (58).

\subsubsection{Extracellular matrix metalloproteinase inducer (EMMPRIN;BSG) expression in the baboon endometrium: Menstrual cycle and endometriosis}

BSG is a glycoprotein which stimulates matrix metalloproteinase (MMP) production based on glycosylation and deglycosylation (59). It has been shown that MMPs like MMP1 and MMP2 are dysregulated in ectopic tissues while endometriosis happens $(60,61)$. For further investigations of other MMPs function, a baboon model is utilized for assessment of sex steroid hormones dysregulations in pathophysiology of endometriosis. They showed that exogenous estrogen and progesterone up-regulated expression of BSG and MMP and all MMPs except MMP-7 revealed significant dysregulation consequently (62).

\subsubsection{A new isoform of steroid receptor coactivator-1 (SRC-1) and endometriosis}

Nuclear receptor-mediated cellular processes are modulated by SRCs in a tissue-selective manner (63). The role of SRCs in progression of endometriosis was not disclosed before the following study. Han et al. proposed different platforms to study SRC-1 function. They used mice autotransplantaion model, xenotransplantation of human biopsy from a patient in SRC-1/--:GFP-expressing mice and xenotransplantation of immortalized human endometrial epithelial cells (IHEECs) into ovariectomized Severe combined immunodeficiency (SCID) mice to evaluate SRC-1 function. SRC-1 proteolytic isoform was increased in ectopic tissue with surgically induced mice and in stromal cells biopsied from endometriosis patients as well. By using transgenic $\mathrm{Tnf}^{-/-}$and $\mathrm{Mmp}^{-/-}$mice, they found that a novel axis of TNF-a/MMP9/SRC-1 isoform helps generating endometriosis. Contribution of animal modelling to this aspect of endometriosis progression is creditable (64).

\subsubsection{Krüppel-like factor 9 (KLF9) deficiency and endometriosis}

KLF9 is a member of Sp/KLF family (65) and its function is closely related to esterogen and Pr dysfunction and endometriosis (66). Heard et al. utilized mice endometriosis model and KLF9 null donors to evaluate hormonal response and signaling pathways. They showed that loss of KLF9 expression provokes endometriosis production and deregulation of Notch and Hedgehog signaling pathways in addition to steroid receptor-regulated pathways (67).

In another sudy by Heard et al., it was revealed that unlike KLF9, KLF13 gene was not statistically associated with lesion development and growth. Also transcription levels of Pgr and Esr1 were not altered despite showing reduction of total Pgr and Esr1 in immunohistochemistry (68).

\subsubsection{Steroid sulfatase and endometriosis}

Steroid sulfatase (STS) is an enzyme involved in estrogen biosynthesis and is expressed in endometrium ectopic tissues (69). Estrone-3-Osulfamate (E2MATE) is irreversible STS inhibitor. Colette et al. used this principle to assess the potency of STS inhibitor as new therapy of endometriosis by using xenotransplanted mouse model of endometriosis. They showed that treatment of mice with E2MATE did not alter plasma estradiol levels, but inhibited STS activity in murine uterus, as well as in induced lesions. E2MATE reduced lesion weight and progesterone expression was increased after treatment in endometriotic tissues (70).

\subsubsection{Cisplatin, letrozole and endometriosis}

Reducing the estrogen secretion is investigated as a protocol for suppressing endometriosis progression using aromatase inhibitors. Aromatization of androgens into estrogens is done by aromatase enzymes. Letrozole is a third-generation aromatase inhibitor (71) and can be a potent drug for endometriosis treatment (72). In a rat model of endometriosis, letrozole induced apoptosis and decreased the volumes and histopathologic scores of the endometriotic foci through decreasing aromatase P450 and cyclooxygenase-2 expression (73). In addition, in rat auto-transplantation model, letrozole increased Bax expression and decreased Bcl-2 expressions as well as aromatase P450 and cyclooxygenase-2, which led to suppression of estrogen secretion (74). Cisplatin is one of the preferred drugs in the treatment of cancer (19). The relation of endometriosis and cancer has raised interests (75). In a study by Li et al. effects of cisplatin and letrozole on rat autotransplantation model of endometriosis were assessed. The serum levels of luteinizing hormone (LH), follicle-stimulating hormone (FSH), prolactin (PRL), testosterone (T), estradiol (E2) and progesterone $(P)$ were assessed. The medication resulted in lower growth of implants, 
lower vascular endothelial growth factor (VEGF), E2, P and higher levels of FSH, LH, and T levels in comparison to control group which is promising for probable treatment of endometriosis (22).

\subsubsection{Bentamapimod induces regression of endometriotic lesions}

In a study, Bentamapimod, a c-Jun N-terminal kinase inhibitor (JNKI) was assessed in xenotransplantation and Auto-transplantation model of endometriosis. Treatment of nude mice with Medroxyprogesterone acetate (MPA) did not ameliorate ectopic lesion but supplementation with Bentamapimod was shown to be significantly effective. Bentamapimod also improved immunity reactions, cytokines functionality. Progesterone resistance without disrupting estrogen related regulations (53).

\subsubsection{Ferulic acid (FA), ligustrazine (LZ) and tetrahydropalmatine (THP) and endometriosis}

FA, LZ and THP were proved to have ameliorating effects on endometriosis state (76). To understand the underlying mechanism of effects, Tang et al. proposed a rat model of endometriosis to benefit from. It resulted decreased levels of Estrogen, GnRH, FSH and LH and lower expression of ER as promising therapeutic effects (77).

\subsubsection{Lipoxin A4 (LXA4) and endometriosis}

Lipoxins are endogenous eicosanoids which have anti-inflammatory properties (78). Previous studies suggested a protective role of LXA4 in the development and progression of experimental endometriosis in mice (79). Due to lack of understanding of this protective mechanism, Kumar et al. used allotransplantation mouse model to reveal underlying mechanisms. They showed that LXA4 treatment significantly reduced ectopic lesion size and downregulated the pro-inflammatory cytokines and angiogenic factor. ERa expression was shown to be diminished by LXA4 and Pr was upregulated respectively (80).

\subsection{Hypothalamic pituitary gonadal (HPG) axis hormones and its role in endometriosis}

\subsubsection{GnRH related endometriosis articles}

\subsubsection{SKI2670 and endometriosis}

$\mathrm{GnRH}$ antagonists are preferred for endometriosis treatment due to instant suppression of gonadotropins and not revealing initial $\mathrm{GnRH}$ stimulation of GnRH agonists (81). In a study by Kim et al., antagonistic potential of SKI2670 in a monkey model was assessed. The treatment showed promising results in comparison to elagolix as a regular treatment as it lowered LH and FSH significantly (82).

\subsubsection{Non-GnRH hormone related endometriosis articles}

\subsubsection{Melatonin and endometriosis}

Some studies revealed that melatonin could decrease the volume of endometriotic foci in rat model of endometriosis $(73,83,84)$. Although these studies indirectly showed the role of this axis in pathogenesis of endometriosis but further investigations using this animal models are necessary to explain the exact mechanisms of melatonin in endometriosis pathogenesis.

\subsubsection{Human chorionic gonadotropin (HCG) and endometriosis}

Wu et al. investigated efficacy of HCG as an option for endometriosis cure by using Auto-transplantation rat model. Shrinkage of endometriotic lesions have been shown in comparison to initial size. It was revealed that HCG ameliorated endometriosis state by reversing leptin upregulation in endometriotic tissues (85).

\subsection{Frequently used methods}

Among section 4 studies, some studies used an approach multiple times. We reviewd them briefly below:

the most popular approach is the well-known rat autotransplantation model from (86). The method is developed based on Sprague-Dawley rats that their slice of uterine were ablated and transplanted to their peritoneal cavity. Eight studies designed their studies based on this 
model untouched or with minor changes which is outstanding after $30+$ years.

The other approach from (87) is based on syngeneic or autotransplantation of uterine tissues from C57BL/6 mice. Two assessed studies have referenced this method as their method of choice. The study was meant to standardize the endometriosis animal modelling for future studies. They showed that orientation of grafted uterine tissue effects growth of ectopic lesions so that the optimal size for transplantation was $2 \mathrm{~mm}$ and perimetrium (outer serous layer of the uterus) with underlying myometrium showed higher growth. The interesting point was that syngeneic or autotransplantation showed identical growth rate.

In 1995, (88) tested the Sampson theory of retrograde menstruation by using baboon models (Papio cynocephalus and Papio anubis. They concluded that intraperitoneal injection of menstrual endometrium was more successful in generating ectopic lesions than luteal endometrium or by retroperitoneal injection means.

Two other studies referenced the method provided from (89). In this model, wild-type C57BL/6 mice as donor and recipient were used. The mice were in diestrous stage when their uterine were removed and divided into $3 \mathrm{~mm}$ pieces. After autotransplantation, it took 14 days for recipient mice to reveal the fluid filled cysts. As said above, usage of $2 \mathrm{~mm}$ pieces would be more ideal for generating ectopic lesions and standardizing the results in some way.

The method by (90) involves using allotransplantation C57BL/6 mice model of endometriosis and doing procedures for 40 days to obtain the final ectopic lesions. Initially menstruation was induced in mice. So that ovariectomized mice were firstly treated with estradiol-17 $\beta$ and then treated with progesterone and sesame oil to induce decidualization. After progesterone withdrawal in 19th day of procedure, the shed

endometrium tissue was collected and injected to donor mice intraperitoneally. Eventually, the recipient mice were sacrificed and the desired ectopic lesions were harvested for assessment. This model also supports the Sampson theory but needs an extensive time and labor to induce.

Another potent translational animal model of endometriosis was introduced by (91). The model was intended to make the process of distinguishing the ectopic lesions from eutopic tissue in donor mice more approachable. In this approach, they used enhanced GFP with C57/B6 background as donor and C57/B6 as recipient mice. So that after the procedure, the lesions were easily distinguishable under florescent microscopy and more intense in estradiol supplemented recipient mice. This model provides a reliable platform to study histological assessment of endometriotic tissue more precisely.

\section{Hormone Based Endometriosis Studies Representing New Induction Methods}

We separated studies with new approaches toward endometriosis induction to assess them exclusively with a novel scoring system. This scoring system (Table 1.) represents a modified combination of previous proposed scoring models to enhance the prediction of drug assessment while utilizing animal models. These studies are categorized as follows (Figure 1).

\subsection{Auto-transplantation models of endometriosis related to SSH and HPG hormones}

\subsubsection{Steroidogenic factor 1 and endometriosis}

Expression of the steroidogenic genes in the ovary is adjusted by steroidogenic factor 1 (SF1) (92). Endometriosis status is reported to be correlated with demethylation of SF1 promoter, leading to the excessive expression of the gene (93). Vasquez et al. utilized an autotransplantation mouse model with activation of SF1 by Cre recombinase system (Pgrcre/- $\mathrm{SF} 1^{\mathrm{LSL} /{ }^{-}}$). They showed generation of enlarged endometrial glands and downregulation of stroma Esr1 and epithelial Pr as a result of SF1 expression. Auto-transplantation of uterine tissue was followed by an increase in size of ectopic lesions in SF1 activated mouse, leading to the deficiency in decidualization process and contributing to the infertility. Serum concentrations of progesterone and estradiol after gonadotropin stimulation were not altered significantly and similar results were noted for uterine and ovarian estradiol levels. They concluded that ovarian tissues of SF1 expressing mouse are in normal state and SF1 expression favors endometriotic lesion establishment which can be considered for future endometriosis model establishment (52).

\subsubsection{Estrogen receptor $\beta$ and endometriosis}

The role of ERß in endometriosis progression was investigated in autotransplantation and xenotransplantation mouse by Han et al thoroughly. They showed an upregulation of ER $\beta$ levels in mouse endometriotic tissues with enhancement of ER $\beta$ activity, which resembles human status. They exploited mutant mice strains like to show ER $\beta$ loss and gain of function effects too. They claimed that gain of ER $\beta$

Page $8 / 24$ 
function (ER ${ }^{-} /^{-}$mice) triggered ectopic lesion growth significantly. They also demonstrated that elevation of ER $\beta$ functionality avoids TNF-a induced apoptosis and boosts proliferation, invasion, and adhesion activities of immortalized human endometriotic epithelial cells in (SCID) mice which can be considered as a suitable xenotransplantation model of endometriosis (94).

\subsubsection{Activated AKT pathway promotes establishment of endometriosis}

Decreased levels of steroid hormones in endometriosis state can be suggested as a risk factor for granulosa cell tumor detection where expression of AKT is upregulated (95). To demonstrate the role of AKT in endometriosis, autologous implantation PR ${ }^{C r e /+} \mathrm{PTEN}^{\mathrm{f} /+}$ mice were used by Kim et al. PTEN (phosphatase and tensin homologue deleted from chromosome 10) is regulatory gene which gets disrupted in the state of cancers (96). They showed that deletion of PTEN increased activation of AKT and decreased levels of Pr in the grafts respectively. They also used MK-2206 as an AKT inhibitor, it showed efficacy by increasing Pr in mouse ectopic tissue and decreasing viability of endometriotic tissue derived cells in vitro. (97).

\subsection{Xenotransplantation models of endometriosis related to SSH and HPG hormones}

\subsubsection{Immortalized human eutopic endometrial stromal cells line for endometriosis studies}

Primary endometrial cells are being preferred extensively for investigation of endometriosis. However, dedifferentiation of cells during culturing, losing hormone and cytokine responsiveness, life shortage, and the change of migration and invasion are the main objections for primary cells. Immortalized primary cell line derived from endometrial stromal cells were utilized from different species (98-100). In a study by Huang et al., initially, eutopic endometrial stromal cells were isolated from a 26-year-old patient suffering from endometriosis. After histological confirmation cells were infected by lentivirus containing Human telomerase reverse transcriptase (hTERT) to produce immortalized cell line (iheESCs) (101).

Cells revealed original morphology during continuous cell cultures, growth rate, mobility and estrogen/progesterone receptor expression. The decidualization of iheESCs was induced by progesterone and cAMP successfully. Cells proliferation was increased by estrogen and lipopolysaccharides (LPS) induced the IL-1 $\beta$ and IL- 6 promoting inflammatory response similar to the human endometriotic lesion derived cells. Moreover, no tumorogenicity was observed following injection of cells into BALB/c nude mice suggesting that this model would be ideal for future studies (101).

It is important to note that four previous studies $(5.1 .1,5.1 .2,5.1 .3,5.2 .1)$ did not consider proper life stages of animals to induce endometriosis. As we know, endometriosis is a disease which happens in reproductive age of women. To provide better translational results, we have to consider the life stages of animal to be adult too (102).

\subsection{Allotransplantation models of endometriosis}

\subsubsection{Estrogen Receptor Signaling and endometriosis}

ERs are proven to possess a key function in estrogen responsiveness (103). aERKO and $\beta E R K O$ mice which lack ERa and ER $\beta$ respectively, were utilized as donor mice in order to assess the ER signaling pathway in recipient wild type mice model of endometriosis and vice versa as well. All grafts transplantations except the one from aERKO to wild type mice responded with growth. They concluded that ectopic lesion development is mostly regulated by estradiol signaling via ERa than ER $\beta$, which can be considered, for future endometriosis modeling. Additionally, models generated in this study can be utilized for ER focused studies and receptor targeting treatments as well. (104). In another study by Burns et al., they utilized the same aERKO and aERKO mice strains as previous study to thoroughly assess initial stages of endometriosis induction. It was revealed that in endometriosis ectopic sites, white blood cells were seen disregard of ERa or estradiol in early stages of endometriosis. Additionally, inflammation and angiogenesis were observed. They suggested that endometriosis development can be categorized into two different phases: an immune-dependent phase and a hormone-dependent phase which should be considered for future studies based on hormonal or immunological approach (105).

\subsubsection{Mouse model of ovarian endometriosis}

In order to address the lack of a specific model to study ovarian endometriosis, Hayashi et al proposed a mouse model of endometriosis for the first time. So that uterus tissue from donor mice was minced and transplanted on ovaries of recipient mice donor mice. The model revealed ectopic lesion growth by four weeks and FSH receptor on the recipient mice were considerably decreased, suggesting fertility problems and CD10 immunopositivity as a marker of endometrial stromal cells outside the uterus (106).

Page $9 / 24$ 


\subsubsection{A high mimicking mouse model of endometriosis}

Using mouse models for endometriosis induction with intact immune system allows researchers to attain better understanding of inflammatory related responses (107). Greaves et al. proposed a mouse model of endometriosis using menstruation induced mouse model as donor mouse and unscathed mouse as recipient. The allotransplantation resulted higher expression of ER $\beta$ in ectopic lesions and CD10 immuno-positivity. Also presence of local macrophage in lesions were suggested to contribute to inflammatory responses making this model an attractive choice to study endometriosis related immunologic responses (90).

\subsubsection{Bazedoxifene and endometriosis}

It has been shown that bazedoxifene as a third-generation selective estradiol receptor modulator, could reduce the size of endometriosis lesions in mice models of endometriosis $(108,109)$. Following bazedoxifene administration in mice, a decrease in expression levels of estrogen receptor mRNA was reported whereas no alteration in expression of Pr mRNA were seen (109).

The selected animal model in these studies was developed based on CD-1 mice. CD-1 mice stock uterine horns were grafted to peritoneum of recipient CD-1 mice to develop endometriosis model and assess Bazedoxifene efficacy in ectopic lesion suppression. The model selection attracts criticism due to selection of mouse stock. CD-1 mice are heterogeneous stock of mice, which are unable to provide the precision and accuracy of results due to undefined genetic variations. The usage of outbred strains for animal modeling is not suggested generally due to ability of accomplishing the same results with much smaller sample size using inbred stocks (110).

\subsection{Spontaneous endometriosis}

\subsubsection{Spontaneous endometriosis in a Mandrill}

Estrogen, progesterone receptors and the CD10 marker are the potential markers of human ectopic endometrial tissues $(111,112)$. Nakamura et al. used these parameters for confirmation of endometriosis existence in a dead mandrill (Mandrillus sphinx) exhibiting haemoperitoneum, petechiae and peritoneal ecchymoses. They noted eutopic and ectopic endometrial stromal cells in uterus and stromallike cells outside the uterus, expressed Pr and CD10 markers. Also normal endometrial glands and the epithelium of the ectopic glands expressed estrogen receptor (113).

\subsubsection{Spontaneous endometriosis in a rhesus macaque}

Assaf and Miller examined a rhesus macaque (Macaca mulatta) which showed difficulty with breathing and weight loss. Their findings confirmed the existence of abdominal endometriosis by powerful expressing of Pr in ectopic lesions accompanied by a slight presence of estrogen receptor (114).

\subsubsection{Endometriosis induced by unopposed estrogenicity}

Nair et al. induced spontaneous endometriosis in baboon by an unopposed estrogenicity approach utilizing Pr antagonist (EC304). Initially they evaluated the role of progesterone in attachment of human endometrial stromal cells in vitro. Progesterone treatment significantly increased the rate of attachment of menstrual endometrial stromal cells peritoneal mesothelium (LP9) and increased rate of invasion. Therefore, they supplemented EC304 with progesterone treatment, which lead to multifocal stacks of differentiated endometrial glands and stroma on the surface of the uterus and peritoneal cavity. Administration of EC304 and progesterone clearly increased the expression of ERa as the direct hallmark of estrogenicity in the endometrial tissue (115).

Figure 1.

Infographic of novel endometriosis induction methods

\section{Conclusion}

Utilizing novel animal models to assess endometriosis pathophysiology is not something new $(86,116)$. There has been extensive research using proposed animal models to assess etiology (117), diagnosis (118), resemblance (119), genetics (120), biomarkers (121) and therapeutics (122) for endometriosis disease. Sometimes these studies have reported promising results to encounter endometriosis as a multifactorial gynecological disease (123).

However, the need for handling this uncomfortable situation is still concerned. For example, despite many efforts, researchers could not propose noninvasive, definite and reliable approaches to diagnose endometriosis yet (124). Therefore, women with probable endometriosis existence still have to deal with pain and side effects of invasive procedure such as laparoscopy woefully.

Page $10 / 24$ 
There is a vast contribution of animal models to this disease in order to eliminate these difficulties. Due to lack of data, major trustworthy reviews like systematic reviews or meta-analysis were unable to address these issues (125). So it is required to look back and revise preclinical procedures like animal modeling to provide more authentic data by enhancing research qualities.

This review has provided new insight through the relation of hormones and endometriosis by gathering recent published data and analyzing it meticulously. The proposed scoring system is designed to compare novel animal models that are proposed through the past decade.

\subsection{Scoring table rationale and evaluation}

We used scoring tables for model assessment which was inspired from (126-128). We also utilized proven hormonal markers (ESR1. PGR, CYP17A1) and other genetic markers (BDNF, AGTR1, CCL2, C3, CD40, TIMP2, SERPINE1, CYP17A1, IGF1, IGF2, IL10, MMP1, MMP7 and $M M P 9$ ) from study by (129) study to evaluate the models. The scoring was designed in a way that a contrast between suitability of available studies would be easily observable.

Our scoring rationale was considered as follows:

1. Non-human primate models gained higher scores than non-human mammals due to more resemblance to human physiologically and pathologically: (Non-human primate $=2$, Non-human mammal $=1$ )

2. Spontaneous disease occurrence which is exclusive for Non-human primates gained highest scores, xenotransplantation models gained higher scores in comparison to autotransplantation / allotransplantation models due to utilizing cells or tissues from human which can be perceived as more closer to human pathological state:

(Spontaneous disease occurrence $=3$, xenotransplantation $=2$, autotransplantation / allotransplantation $=1$ )

3. Consistent pharmacological effects with humans by available verified drugs can be promising criteria for better future translational animal modeling:

(Consistent drug effects with human $=+1$, No pharmacological evaluation $=0$, Non-consistent drug effects with human $=-1$ )

4. Relevant life stage in animal models is a key factor for suitability due to occurrence of different outcomes with drug treatments in different stages of life:

(Identical life stage $=+1$, Not mentioned $=0$, Non-identical life stage $=-1$ )

5. Previous studies have suggested extensive hormonal dysregulations in endometriotic animal models, which can be in compliance with human photogenic state. The more similar the dysregulation, the better translational animal model would be:

(More than one similar hormonal marker regulation to human $=+2$, Single marker regulation similarity to human $=+1$, Not mentioned $=0$, Non-consistent hormonal marker(s) regulation(s) with human $=-1$ )

6. There are also numerous genes which get disrupted in the state of endometriosis. gene regulations can be consistent with human body dysregulations or not:

(More than one similar gene expression with human $=+2$, Single gene expression similarity with human $=+1$, No genetic evaluation $=0$, Non-consistent gene(s) regulation(s) with human $=-1$ )

7. One of the traditional ways of validating endometriosis existence is laparoscopy. The evaluation of engaged tissues by staining or observation of ectopic lesions is still the gold standard for diagnosis of the disease:

(Ectopic lesion(s) detection $=+1$, Not mentioned $=0$, No ectopic lesion(s) detection $=-1$ )

This table also provides novel insight for future studies to choose the most suitable model. It is worth mentioning despite achieving less score for non-human mammals in comparison to non-human primates, they benefit from wide availability, easy handling, cost effectiveness, faster growth and breeding. In non-human mammals segment, study by $(130,131)$ and $(90)$ gained the highest score by providing key elements and resemblance to human endometriosis. (90) proposed their model in non-immunocompromised mice, which can be considered as an advantage for studies involving immunologic topics. While in humans endometriosis is an issue with adult women, 
most of other studies in this category neglected utilizing adult animals (102). This simple selection can produce inaccurate results for clinical trials and major analyzes. In spite of providing a considerable approach for xenotransplantation, (101) did not provide adequate animal modelling assessment. Although, the mouse model by $(108,109)$ gained a considerable grade, it is not recommended to use the outbred stock (CD-1) due to genetic variation and suitable availability of other inbred mice strains.

Transgenic animals for endometriosis studies are gaining increasing attention for further investigation of the disease. Some of this transgenic mice exhibit endometriosis features, while the others just facilitate the investigation of the disease and induction of endometriotic state is done by utilizing the previous developed methods. Transgenic animal models in this field can be one of the most promising tools to examine functions of various genes precisely.

Non-human primates are considered to be very similar to humans genetically and physiologically. In addition, they are able to develop spontaneous endometriosis, which can be a positive factor in research terms. In addition to similarities to human, endometriosis is confirmed more accurately considering hormonal assessment; therefore, they achieved higher scoring results. In this segment, (115) has proposed the best model scoring wise. Unlike other models of non-human primates, this model utilized anti progestin to develop endometriotic lesions in baboons. Therefore, can be proposed as best available animal model for hormone related endometriosis assessment.

\section{Abbreviations}

Sex steroid hormones: SSH

Hypothalamic pituitary gonadal axis: HPG axis

Luteinizing hormone: LH

Follicle-stimulating hormone: FSH

Gonadotropin-releasing hormone: $\mathrm{GnRH}$

Estrogen receptors: ERs

Progesterone receptors: PRs

G protein-coupled estrogen receptor 1: GPER1

Steroidogenic factor 1: SF1

High-fat diet: HFD

Matrix metalloproteinase: MMP

Extracellular matrix metalloproteinase inducer: BSG

Steroid receptor coactivator-1: SRC-1

Immortalized human endometrial epithelial cells: IHEECs

Severe combined immunodeficiency: SCID

Steroid sulfatase: STS

Estradiol: E2

Progesterone: $\mathrm{P}$

Vascular endothelial growth factor: VEGF

Testosterone: T

Lipoxin A4: LXA4

Page 12/24 


\section{Declarations}

\subsection{Ethics approval and consent to participate}

Not applicable.

\subsection{Consent for publication}

Not applicable.

\subsection{Availability of data and materials}

Not applicable.

\subsection{Competing interests}

Authors have declared no conflict of interests.

\subsection{Funding}

No funding was received for this study.

\subsection{Authors' contributions}

A. T., A. S., and M. M. conceived and designed the format of the manuscript. A. S. and A. Z. collected the data, and drafted and edited the manuscript. A. T., A. S., A. Z., and M. M. drew the Figures and Tables. All the authors reviewed the manuscript and all of them contributed to the critical reading and discussion of the manuscript. All authors have read and agreed to the published version of the manuscript.

\subsection{Acknowledgements}

Not applicable.

\section{References}

1. Sarria-Santamera A, Orazumbekova B, Terzic M, Issanov A, Chaowen C, Asúnsolo-del-Barco A, editors. Systematic Review and MetaAnalysis of Incidence and Prevalence of Endometriosis. Healthcare; 2021: Multidisciplinary Digital Publishing Institute.

2. Malvezzi H, Marengo EB, Podgaec S, de Azevedo Piccinato C. Endometriosis: current challenges in modeling a multifactorial disease of unknown etiology. Journal of Translational Medicine. 2020;18(1):1-21.

3. Malutan AM, Drugan T, Costin N, Ciortea R, Bucuri C, Rada MP, et al. Pro-inflammatory cytokines for evaluation of inflammatory status in endometriosis. Central-European journal of immunology. 2015;40(1):96.

4. Riccio LdGC, Santulli P, Marcellin L, Abrão MS, Batteux F, Chapron C. Immunology of endometriosis. Best practice \& research Clinical obstetrics \& gynaecology. 2018;50:39-49.

5. Bellelis P, Podgaec S, Abrão MS. Environmental factors and endometriosis. Revista da Associação Médica Brasileira. 2011;57:456-61.

6. Sapkota Y, Steinthorsdottir V, Morris AP, Fassbender A, Rahmioglu N, De Vivo I, et al. Meta-analysis identifies five novel loci associated with endometriosis highlighting key genes involved in hormone metabolism. Nature communications. 2017;8(1):1-12.

7. Maddern J, Grundy L, Castro J, Brierley SM. Pain in endometriosis. Frontiers in Cellular Neuroscience. $2020 ; 14$.

8. Medicine PCotASfR. Endometriosis and infertility: a committee opinion. Fertility and sterility. 2012;98(3):591-8. 
9. Sampson JA. The development of the implantation theory for the origin of peritoneal endometriosis. American Journal of Obstetrics and Gynecology. 1940;40(4):549-57.

10. Bulun SE, Monsivais D, Kakinuma T, Furukawa Y, Bernardi L, Pavone ME, et al. Molecular biology of endometriosis: from aromatase to genomic abnormalities. Seminars in Reproductive Medicine. 2015;33(3):220-4.

11. Giudice LC. Clinical practice. Endometriosis. New England Journal of Medicine. 2010;362(25):2389-98.

12. Stratton P, Berkley KJ. Chronic pelvic pain and endometriosis: translational evidence of the relationship and implications. Human Reproduction Update. 2011;17(3):327-46.

13. Bulun SE, Monsavais D, Pavone ME, Dyson M, Xue Q, Attar E, et al. Role of estrogen receptor- $\beta$ in endometriosis. Seminars in Reproductive Medicine. 2012;30(1):39-45.

14. Prossnitz ER, Barton M. The G-protein-coupled estrogen receptor GPER in health and disease. Nature Reviews Endocrinology. 2011;7(12):715-26.

15. Erol A, Ho AM, Winham SJ, Karpyak VM. Sex hormones in alcohol consumption: a systematic review of evidence. Addict Biol. 2019;24(2):157-69.

16. Chen Y, Chen C, Shi S, Han J, Wang J, Hu J, et al. Endometriotic implants regress in rat models treated with puerarin by decreasing estradiol level. Reproductive Sciences. 2011;18(9):886-91.

17. Coudyzer P, Lemoine P, Po C, Jordan BF, Van Der Smissen P, Courtoy PJ, et al. Induction of post-menstrual regeneration by ovarian steroid withdrawal in the functionalis of xenografted human endometrium. Human Reproduction. 2015;30(5):1156-68.

18. Zhao C, Wu LS-F, Barner R. Pathogenesis of ovarian clear cell adenofibroma, atypical proliferative (borderline) tumor, and carcinoma: clinicopathologic features of tumors with endometriosis or adenofibromatous components support two related pathways of tumor development. Journal of Cancer. 2011;2:94.

19. Wang Q-E, Milum K, Han C, Huang Y-W, Wani G, Thomale J, et al. Differential contributory roles of nucleotide excision and homologous recombination repair for enhancing cisplatin sensitivity in human ovarian cancer cells. Molecular cancer. 2011;10(1):1-12.

20. Noble LS, Simpson ER, Johns A, Bulun SE. Aromatase expression in endometriosis. The Journal of Clinical Endocrinology \& Metabolism. 1996;81(1):174-9.

21. Oner G, Ozcelik B, Ozgun MT, Serin IS, Ozturk F, Basbug M. The effects of metformin and letrozole on endometriosis and comparison of the two treatment agents in a rat model. Human reproduction. 2010;25(4):932-7.

22. Li Z, Liu H, He Z, Zhang G, Lang J. Effects of cisplatin and letrozole on surgically induced endometriosis and comparison of the two medications in a rat model. European Journal of Pharmaceutical Sciences. 2016;93:132-40.

23. Zheng Y, Bai C, Wang X. Telocyte morphologies and potential roles in diseases. Journal of cellular physiology. 2012;227(6):2311-7.

24. Hatta K, Huang ML, Weisel RD, Li RK. Culture of rat endometrial telocytes. Journal of cellular and molecular medicine. 2012;16(7):1392-6.

25. Yang X-J, Xu J-Y, Shen Z-J, Zhao J. Immunohistochemical alterations of cajal-like type of tubal interstitial cells in women with endometriosis and tubal ectopic pregnancy. Archives of gynecology and obstetrics. 2013;288(6):1295-300.

26. Yang XJ, Yang J, Liu Z, Yang G, Shen ZJ. Telocytes damage in endometriosis-affected rat oviduct and potential impact on fertility. Journal of Cellular and Molecular Medicine. 2015;19:452-62.

27. Li R, Hu Z, Sun S-Y, Chen ZG, Owonikoko TK, Sica GL, et al. Niclosamide overcomes acquired resistance to erlotinib through suppression of STAT3 in non-small cell lung cancer. Molecular cancer therapeutics. 2013;12(10):2200-12.

28. Prather GR, MacLean JA, Shi M, Boadu DK, Paquet M, Hayashi K. Niclosamide as a potential nonsteroidal therapy for endometriosis that preserves reproductive function in an experimental mouse model. Biology of Reproduction. 2016;95:76.

29. Tokushige N, Markham R, Russell P, Fraser IS. Nerve fibres in peritoneal endometriosis. Human reproduction. 2006;21(11):3001-7.

30. Weinstein BM. Vessels and nerves: marching to the same tune. Cell. 2005;120(3):299-302.

31. Greaves E, Collins F, Esnal-Zufiaurre A, Giakoumelou S, Horne AW, Saunders PTK. Estrogen receptor (ER) agonists differentially regulate neuroangiogenesis in peritoneal endometriosis via the repellent factor SLIT3. Endocrinology2014. p. 4015-26.

32. Greaves E, Temp J, Esnal-Zufiurre A, Mechsner S, Horne AW, Saunders PTK. Estradiol Is a Critical Mediator of Macrophage-Nerve Cross Talk in Peritoneal Endometriosis. American Journal of Pathology. 2015;185:2286-97.

33. Piotrowski PC, Kwintkiewicz J, Rzepczynska IJ, Seval Y, Cakmak H, Arici A, et al. Statins inhibit growth of human endometrial stromal cells independently of cholesterol availability. Biology of reproduction. 2006;75(1):107-11.

34. Bruner-Tran KL, Osteen KG, Duleba AJ. Simvastatin protects against the development of endometriosis in a nude mouse model. The Journal of Clinical Endocrinology \& Metabolism. 2009;94(7):2489-94. 
35. Taylor HS, Alderman M, D’Hooghe TM, Fazleabas AT, Duleba AJ. Effect of simvastatin on baboon endometriosis. Biology of Reproduction. 2017;97:32-8.

36. Zhou H-B, Comninos JS, Stossi F, Katzenellenbogen BS, Katzenellenbogen JA. Synthesis and evaluation of estrogen receptor ligands with bridged oxabicyclic cores containing a diarylethylene motif: estrogen antagonists of unusual structure. Journal of medicinal chemistry. 2005;48(23):7261-74.

37. De Angelis M, Stossi F, Carlson KA, Katzenellenbogen BS, Katzenellenbogen JA. Indazole estrogens: Highly selective ligands for the estrogen receptor $\beta$. Journal of medicinal chemistry. 2005;48(4):1132-44.

38. Zhao Y, Gong P, Chen Y, Nwachukwu JC, Srinivasan S, Ko C, et al. Dual suppression of estrogenic and inflammatory activities for targeting of endometriosis. Science translational medicine. 2015;7(271):271ra9-ra9.

39. Attia GR, Zeitoun K, Edwards D, Johns A, Carr BR, Bulun SE. Progesterone receptor isoform A but not B is expressed in endometriosis. The Journal of Clinical Endocrinology \& Metabolism. 2000;85(8):2897-902.

40. Burney R, Hamilton A, Aghajanova L, Vo K, Nezhat C, Lessey B, et al. MicroRNA expression profiling of eutopic secretory endometrium in women with versus without endometriosis. Molecular human reproduction. 2009;15(10):625-31.

41. Fung JN, Rogers PA, Montgomery GW. Identifying the biological basis of GWAS hits for endometriosis. Biology of Reproduction. 2015;92(4):87, 1-12.

42. Barragan F, Irwin JC, Balayan S, Erikson DW, Chen JC, Houshdaran S, et al. Human endometrial fibroblasts derived from mesenchymal progenitors inherit progesterone resistance and acquire an inflammatory phenotype in the endometrial niche in endometriosis. Biology of reproduction. 2016;94(5):118, 1-20.

43. Al-Sabbagh M, Lam EW-F, Brosens JJ. Mechanisms of endometrial progesterone resistance. Molecular and cellular endocrinology. 2012;358(2):208-15.

44. Yuan P, Huang Y, Wu H, Teng Z, Zhang J, Xin X. Induction of a local pseudo-pregnancy via levonorgestrel-loaded microspheres for the treatment of endometriosis in a rabbit model. Human Reproduction. 2010;25(2):462-9.

45. Yuan P, Chen B, Huang Y, Xin X. Long-term regression of experimental endometriosis in a rat model treated with local application of levonorgestrel-loaded biodegradable microspheres. Human Reproduction. 2012;27(7):2089-95.

46. Sitruk-Ware R. New progestagens for contraceptive use. Human reproduction update. 2006;12(2):169-78.

47. Duc I, Botella J, Delansorne R, Paris J. Interaction of [3H] nomegestrol acetate with cytosolic progesterone receptors from the rat uterus. Steroids. 1991;56(6):325-8.

48. Sitruk-Ware R. Reprint of pharmacological profile of progestins. Maturitas. 2008;61(1-2):151-7.

49. Zhang J, Zhu Y, Zhou X, Hao S, Xie S, Zhou J, et al. Evaluation of biodegradable microspheres containing nomegestrol acetate in a rat model of endometriosis. European Journal of Pharmaceutical Sciences. 2014;65:15-20.

50. Monsivais D, Dyson M, Yin P, Coon J, Navarro A, Feng G, et al. ERß-and prostaglandin E2-regulated pathways integrate cell proliferation via Ras-like and estrogen-regulated growth inhibitor in endometriosis. Molecular endocrinology. 2014;28(8):1304-15.

51. Mishra A, Galvankar M, Singh N, Modi D. Spatial and temporal changes in the expression of steroid hormone receptors in mouse model of endometriosis. Journal of Assisted Reproduction and Genetics. 2020;37:1069-81.

52. Vasquez YM, Wu SP, Anderson ML, Hawkins SM, Creighton CJ, Ray M, et al. Endometrial expression of steroidogenic factor 1 promotes cystic glandular morphogenesis. Molecular Endocrinology. 2016;30:518-32.

53. Hussein M, Chai DC, Kyama CM, Mwenda JM, Palmer SS, Gotteland J-P, et al. c-Jun NH2-terminal kinase inhibitor bentamapimod reduces induced endometriosis in baboons: an assessor-blind placebo-controlled randomized study. Fertility and sterility. 2016;105(3):815-24. e5.

54. Palmer SS, Altan M, Denis D, Tos EG, Gotteland J-P, Osteen KG, et al. Bentamapimod (JNK inhibitor AS602801) induces regression of endometriotic lesions in animal models. Reproductive Sciences. 2016;23(1):11-23.

55. Attaman JA, Stanic AK, Kim M, Lynch MP, Rueda BR, Styer AK. The anti-inflammatory impact of omega-3 polyunsaturated Fatty acids during the establishment of endometriosis-like lesions. American Journal of Reproductive Immunology. 2014;72(4):392-402.

56. Fader AN, Arriba LN, Frasure HE, von Gruenigen VE. Endometrial cancer and obesity: epidemiology, biomarkers, prevention and survivorship. Gynecologic oncology. 2009;114(1):121-7.

57. Nava-González EJ, de la Garza-Casas YE, Salazar-Montalvo RG, Gallegos-Cabriales EC. Relationship among anthropometric and glucometabolic parameters, bone mineral density and endometriosis. Revista Médica del Instituto Mexicano del Seguro Social.

2013;51(5):522-31. 
58. Heard ME, Melnyk SB, Simmen FA, Yang Y, Pabona JMP, Simmen RCM. High-fat diet promotion of endometriosis in an immunocompetent mouse model is associated with altered peripheral and ectopic lesion redox and inflammatory status. Endocrinology. 2016;157:2870-82.

59. Sun J, Hemler ME. Regulation of MMP-1 and MMP-2 production through CD147/extracellular matrix metalloproteinase inducer interactions. Cancer research. 2001;61(5):2276-81.

60. Gottschal C, Malberg K, Arndt M, Schmitt J, Roessner A, Schultze D, et al. Matrix metalloproteinases and TACE play a role in the pathogenesis of endometriosis. Cellular Peptidases in Immune Functions and Diseases 2: Springer; 2002. p. 483-6.

61. Wenzl RJ, Heinzl H. Localization of matrix metalloproteinase-2 in uterine endometrium and ectopic implants. Gynecologic and obstetric investigation. 1998;45(4):253-7.

62. Braundmeier AG, Fazleabas AT, Nowak RA. Extracellular matrix metalloproteinase inducer expression in the baboon endometrium: menstrual cycle and endometriosis. Reproduction. 2010;140(6):911-20.

63. Lonard DM, O'malley BW. Nuclear receptor coregulators: modulators of pathology and therapeutic targets. Nature Reviews Endocrinology. 2012;8(10):598-604.

64. Han SJ, Hawkins SM, Begum K, Jung SY, Kovanci E, Qin J, et al. A new isoform of steroid receptor coactivator-1 is crucial for pathogenic progression of endometriosis. Nature medicine. 2012;18(7):1102-11.

65. Suske G, Bruford E, Philipsen S. Mammalian SP/KLF transcription factors: bring in the family. Genomics. 2005;85(5):551-6.

66. Pabona JMP, Simmen FA, Nikiforov MA, Zhuang D, Shankar K, Velarde MC, et al. Krüppel-like factor 9 and progesterone receptor coregulation of decidualizing endometrial stromal cells: implications for the pathogenesis of endometriosis. The Journal of Clinical Endocrinology \& Metabolism. 2012;97(3):E376-E92.

67. Heard ME, Simmons CD, Simmen FA, Simmen RCM. Krüppel-like factor 9 deficiency in uterine endometrial cells promotes ectopic lesion establishment associated with activated notch and hedgehog signaling in a mouse model of endometriosis. Endocrinology. 2014;155(4):1532-46.

68. Heard ME, Velarde MC, Giudice LC, Simmen FA, Simmen RCM. Krüppel-like Factor 13 deficiency in uterine endometrial cells contributes to defective steroid hormone receptor signaling but not lesion establishment in a mouse model of endometriosis. Biology of Reproduction2015. p. 140.

69. Šmuc T, Pucelj MR, Šinkovec J, Husen B, Thole H, Rižner TL. Expression analysis of the genes involved in estradiol and progesterone action in human ovarian endometriosis. Gynecological Endocrinology. 2007;23(2):105-11.

70. Colette S, Defrere S, Lousse J-C, Van Langendonckt A, Gotteland J, Loumaye E, et al. Inhibition of steroid sulfatase decreases endometriosis in an in vivo murine model. Human Reproduction. 2011;26(6):1362-70.

71. McCloskey EV, Hannon RA, Lakner G, Fraser WD, Clack G, Miyamoto A, et al. Effects of third generation aromatase inhibitors on bone health and other safety parameters: results of an open, randomised, multi-centre study of letrozole, exemestane and anastrozole in healthy postmenopausal women. European Journal of Cancer. 2007;43(17):2523-31.

72. Ceyhan ST, Onguru O, Fidan U, Ide T, Yaman H, Kilic S, et al. Comparison of aromatase inhibitor (letrozole) and immunomodulators (infliximab and etanercept) on the regression of endometriotic implants in a rat model. European Journal of Obstetrics \& Gynecology and Reproductive Biology. 2011;154(1):100-4.

73. Yildirim G, Attar R, Ozkan F, Kumbak B, Ficicioglu C, Yesildaglar N. The effects of letrozole and melatonin on surgically induced endometriosis in a rat model: a preliminary study. Fertility and sterility. 2010;93(6):1787-92.

74. Xia X, Guo L, Su J, Fang X. Effect of letrozole on endometrosis and apoptosis of ectopic endometrial cells in rats. Zhong Nan Da Xue Xue Bao Yi Xue Ban. 2013;38(1):54-9.

75. Wang S, Qiu L, Lang JH, Shen K, Huang HF, Pan LY, et al. Prognostic analysis of endometrioid epithelial ovarian cancer with or without endometriosis: a 12-year cohort study of Chinese patients. American journal of obstetrics and gynecology. 2013;209(3):241. e1-. e9.

76. Yang Y, Wang X, Chen G, Deng L, Xu X. Research of therapeutical effect and immunologic mechanism of Jiawei Foshou San on model rats of endometriosis. Zhongguo Zhong yao za zhi= Zhongguo zhongyao zazhi= China journal of Chinese materia medica. 2011;36(21):3001-6.

77. Tang Q, Shang F, Wang X, Yang Y, Chen G, Chen Y, et al. Combination use of ferulic acid, ligustrazine and tetrahydropalmatine inhibits the growth of ectopic endometrial tissue: A multi-target therapy for endometriosis rats. Journal of Ethnopharmacology2014. p. 121825.

78. Serhan CN. Lipoxins and aspirin-triggered 15-epi-lipoxins are the first lipid mediators of endogenous anti-inflammation and resolution. Prostaglandins, leukotrienes and essential fatty acids. 2005;73(3-4):141-62. 
79. Xu Z, Zhao F, Lin F, Chen J, Huang Y. Lipoxin A 4 Inhibits the Development of Endometriosis in Mice: The Role of Anti-Inflammation and Anti-Angiogenesis. American journal of reproductive immunology. 2012;67(6):491-7.

80. Kumar R, Clerc A-C, Gori I, Russell R, Pellegrini C, Govender L, et al. Lipoxin A (4) prevents the progression of de novo and established endometriosis in a mouse model by attenuating prostaglandin E (2) production and estrogen signaling. PLoS ONE. 2014;9(2):e89742.

81. Küpker W, Felberbaum R, Krapp M, Schill T, Malik E, Diedrich K. Use of GnRH antagonists in the treatment of endometriosis. Reproductive biomedicine online. 2002;5(1):12-6.

82. Kim SM, Yoo T, Lee SY, Kim EJ, Lee SM, Lee MH, et al. Effect of SKI2670, a novel, orally active, non-peptide GnRH antagonist, on hypothalamic-pituitary-gonadal axis. Life Sciences2015. p. 166-74.

83. Cetinkaya N, Attar R, Yildirim G, Ficicioglu C, Ozkan F, Yilmaz B, et al. The effects of different doses of melatonin treatment on endometrial implants in an oophorectomized rat endometriosis model. Archives of Gynecology and Obstetrics. 2014;291(3):591-8.

84. Koc O, Gunduz BI, Topcuoglu A, Bugdayci GI, Yilmaz F, Duran BI. Effects of pinealectomy and melatonin supplementation on endometrial explants in a rat model. European Journal of Obstetrics, Gynecology and Reproductive Biology. 2010;153(1):72-6.

85. Wu L-L, Pang R-P, Yin Y-Z, Shen K-F, Zhang P-Z. Human chorionic gonadotropin improves endometriosis through downregulation of leptin expression in rats. Gynecologic and Obstetric Investigation. 2015;79(3):189-94.

86. Vernon MW, Wilson EA. Studies on the surgical induction of endometriosis in the rat. Fertility and sterility. 1985;44(5):684-94.

87. Körbel C, Menger MD, Laschke MW. Size and spatial orientation of uterine tissue transplants on the peritoneum crucially determine the growth and cyst formation of endometriosis-like lesions in mice. Human reproduction. 2010;25(10):2551-8.

88. D'Hooghe TM, Bambra CS, Raeymaekers BM, De Jonge I, Lauweryns JM, Koninckx PR. Intrapelvic injection of menstrual endometrium causes endometriosis in baboons (Papio cynocephalus and Papio anubis). American journal of obstetrics and gynecology. 1995;173(1):125-34.

89. Zhao Y, Li Q, Katzenellenbogen BS, Lau LF, Taylor RN, Bagchi IC, et al. Estrogen-induced CCN1 is critical for establishment of endometriosis-like lesions in mice. Molecular Endocrinology. 2014;28(12):1934-47.

90. Greaves E, Cousins FL, Murray A, Esnal-Zufiaurre A, Fassbender A, Horne AW, et al. A novel mouse model of endometriosis mimics human phenotype and reveals insights into the inflammatory contribution of shed endometrium. The American journal of pathology. 2014;184(7):1930-9.

91. Hirata T, Osuga Y, Yoshino O, Hirota Y, Harada M, Takemura Y, et al. Development of an experimental model of endometriosis using mice that ubiquitously express green fluorescent protein. Human reproduction. 2005;20(8):2092-6.

92. Ingraham HA, Lala DS, Ikeda Y, Luo X, Shen W-H, Nachtigal MW, et al. The nuclear receptor steroidogenic factor 1 acts at multiple levels of the reproductive axis. Genes \& development. 1994;8(19):2302-12.

93. Xue Q, Lin Z, Yin P, Milad MP, Cheng Y-H, Confino E, et al. Transcriptional activation of steroidogenic factor-1 by hypomethylation of the 5' CpG island in endometriosis. The Journal of Clinical Endocrinology \& Metabolism. 2007;92(8):3261-7.

94. Han SJ, Jung SY, Wu S-P, Hawkins SM, Park MJ, Kyo S, et al. Estrogen receptor $\beta$ modulates apoptosis complexes and the inflammasome to drive the pathogenesis of endometriosis. Cell. 2015;163(4):960-74.

95. Asghari S, Valizadeh Dizajeykan A, Ahmadi M, Barzegari A, Rikhtegar R, Dolati S, et al. Evaluation of ovarian cancer risk in granulosa cells treated with steroid-depleted endometriosis serum: Role of NF-KB/RelA and AKT. Journal of cellular physiology. 2019;234(7):12011-8.

96. Steck PA, Pershouse MA, Jasser SA, Yung WA, Lin H, Ligon AH, et al. Identification of a candidate tumour suppressor gene, MMAC1, at chromosome 10q23. 3 that is mutated in multiple advanced cancers. Nature genetics. 1997;15(4):356-62.

97. Kim TH, Yu Y, Luo L, Lydon JP, Jeong J-W, Kim JJ. Activated AKT pathway promotes establishment of endometriosis. Endocrinology. 2014;155(5):1921-30.

98. Ghobadi F, Rahmanifar F, Mehrabani D, Tamadon A, Dianatpour M, Zare S, et al. Endometrial mesenchymal stem stromal cells in mature and immature sheep: An in vitro study. International Journal of Reproductive BioMedicine. 2018;16(2):83.

99. Mehrabani D, Rahmanifar F, Mellinejad M, Tamadon A, Dianatpour M, Zare S, et al. Isolation, culture, characterization, and adipogenic differentiation of heifer endometrial mesenchymal stem cells. Comparative Clinical Pathology. 2015;24(5):1159-64.

100. Tamadon A, Mehrabani D, Zarezadeh Y, Rahmanifar F, Dianatpour M, Zare S. Caprine endometrial mesenchymal stromal stem cell: multilineage potential, characterization, and growth kinetics in breeding and anestrous stages. Veterinary medicine international. $2017 ; 2017$.

101. Huang ZX, Mao XM, Lin DC, Hong YH, Liang GS, Chen QX, et al. Establishment and characterization of immortalized human eutopic endometrial stromal cells. American Journal of Reproductive Immunology. 2020;83:e13213.

Page $17 / 24$ 
102. Brust V, Schindler PM, Lewejohann L. Lifetime development of behavioural phenotype in the house mouse (Mus musculus). Frontiers in Zoology. 2015;12(1):1-14.

103. Couse JF, Curtis SW, Washburn TF, Lindzey J, Golding TS, Lubahn DB, et al. Analysis of transcription and estrogen insensitivity in the female mouse after targeted disruption of the estrogen receptor gene. Molecular endocrinology. 1995;9(11):1441-54.

104. Burns KA, Rodriguez KF, Hewitt SC, Janardhan KS, Young SL, Korach KS. Role of estrogen receptor signaling required for endometriosislike lesion establishment in a mouse model. Endocrinology. 2012;153(8):3960-71.

105. Burns KA, Thomas SY, Hamilton KJ, Young SL, Cook DN, Korach KS. Early endometriosis in females is directed by immune-Mediated estrogen receptor a and IL-6 cross-Talk. Endocrinology. 2018;159:103-18.

106. Hayashi S, Nakamura T, Motooka Y, Ito F, Jiang L, Akatsuka S, et al. Novel ovarian endometriosis model causes infertility via ironmediated oxidative stress in mice. Redox Biol. 2020;37:101726.

107. Somigliana E, Viganò P, Zingrillo B, Ranieri S, Filardo $P$, Candiani M, et al. Induction of endometriosis in the mouse inhibits spleen leukocyte function. Acta obstetricia et gynecologica Scandinavica. 2001;80(3):200-.

108. Kulak Jr J, Fischer C, Komm B, Taylor HS. Treatment with bazedoxifene, a selective estrogen receptor modulator, causes regression of endometriosis in a mouse model. Endocrinology. 2011;152(8):3226-32.

109. Naqvi H, Sakr S, Presti T, Krikun G, Komm B, Taylor HS. Treatment with bazedoxifene and conjugated estrogens results in regression of endometriosis in a murine model. Biology of Reproduction. 2014;90(6):121.

110. Chia R, Achilli F, Festing MF, Fisher EM. The origins and uses of mouse outbred stocks. Nature genetics. 2005;37(11):1181-6.

111. Sumathi VP, McCluggage W. CD10 is useful in demonstrating endometrial stroma at ectopic sites and in confirming a diagnosis of endometriosis. Journal of clinical pathology. 2002;55(5):391-2.

112. Jones R, Bulmer J, Searle R. Immunohistochemical characterization of proliferation, oestrogen receptor and progesterone receptor expression in endometriosis: comparison of eutopic and ectopic endometrium with normal cycling endometrium. Human Reproduction. 1995;10(12):3272-9.

113. Nakamura S, Ochiai K, Ochi A, Ito M, Kamiya T, Yamamoto H. Spontaneous endometriosis in a mandrill (Mandrillus sphinx). Journal of Comparative Pathology. 2012;147(2):386-90.

114. Assaf BT, Miller AD. Pleural endometriosis in an aged rhesus macaque (Macaca mulatta): a histopathologic and immunohistochemical study. Veterinary Pathology Online. 2012;49(4):636-41.

115. Nair HB, Baker R, Owston MA, Escalona R, Dick EJ, VandeBerg JL, et al. An efficient model of human endometriosis by induced unopposed estrogenicity in baboons. Oncotarget. 2016;7:10857-69.

116. Jones RC. The effect of a luteinizing hormone-releasing hormone antagonist on experimental endometriosis in the rat. European Journal of Endocrinology. 1987;114(3):379-82.

117. Mishra A, Galvankar M, Vaidya S, Chaudhari U, Modi D. Mouse model for endometriosis is characterized by proliferation and inflammation but not epithelial-to-mesenchymal transition and fibrosis. J Biosci. 2020;45.

118. Nishimoto-Kakiuchi A, Netsu S, Okabayashi S, Taniguchi K, Tanimura H, Kato A, et al. Spontaneous endometriosis in cynomolgus monkeys as a clinically relevant experimental model. Hum Reprod. 2018;33(7):1228-36.

119. Persoons E, De Clercq K, Van den Eynde C, Pinto S, Luyten K, Van Bree R, et al. Mimicking Sampson's Retrograde Menstrual Theory in Rats: A New Rat Model for Ongoing Endometriosis-Associated Pain. Int J Mol Sci. 2020;21(7).

120. Konno R, Fujiwara H, Netsu S, Odagiri K, Shimane M, Nomura H, et al. Gene expression profiling of the rat endometriosis model. Am J Reprod Immunol. 2007;58(4):330-43.

121. Cosar E, Mamillapalli R, Moridi I, Duleba A, Taylor HS. Serum MicroRNA Biomarkers Regulated by Simvastatin in a Primate Model of Endometriosis. Reprod Sci. 2019;26(10):1343-50.

122. Kim YS, Kim YJ, Kim MJ, Lee SJ, Kwon H, Lee JH. Novel Medicine for Endometriosis and Its Therapeutic Effect in a Mouse Model. Biomedicines. 2020;8(12).

123. Ma Y, He YL. Study of an antiangiogenesis gene therapy with endostatin on endometriosis in the nude mouse model. Clin Exp Obstet Gynecol. 2014;41(3):328-34.

124. Gupta D, Hull ML, Fraser I, Miller L, Bossuyt PM, Johnson N, et al. Endometrial biomarkers for the non-invasive diagnosis of endometriosis. Cochrane Database Syst Rev. 2016;4(4):Cd012165.

125. Nisenblat V, Bossuyt PM, Shaikh R, Farquhar C, Jordan V, Scheffers CS, et al. Blood biomarkers for the non-invasive diagnosis of endometriosis. Cochrane Database Syst Rev. 2016;2016(5):Cd012179. 
126. Ferreira GS, Veening-Griffioen DH, Boon WP, Moors EH, van Meer PJ. Levelling the translational gap for animal to human efficacy data. Animals. 2020;10(7):1199.

127. Denayer T, Stöhr T, Van Roy M. Animal models in translational medicine: Validation and prediction. New Horizons in Translational Medicine. 2014;2(1):5-11.

128. Sams-Dodd F. Strategies to optimize the validity of disease models in the drug discovery process. Drug discovery today. 2006;11(78):355-63.

129. Vargas E, Aghajanova L, Gemzell-Danielsson K, Altmäe S, Esteban FJ. Cross-disorder analysis of endometriosis and its comorbid diseases reveals shared genes and molecular pathways and proposes putative biomarkers of endometriosis. Reproductive biomedicine online. 2020;40(2):305-18.

130. Burns KA, Thomas SY, Hamilton KJ, Young SL, Cook DN, Korach KS. Early endometriosis in females is directed by immune-Mediated estrogen receptor a and IL-6 cross-Talk. Endocrinology2018. p. 103-18.

131. Burns KA, Rodriguez KF, Hewitt SC, Janardhan KS, Young SL, Korach KS. Role of estrogen receptor signaling required for endometriosislike lesion establishment in a mouse model. Endocrinology2012. p. 3960-71.

132. Nakamura S, Ochiai K, Ochi A, Ito M, Kamiya T, Yamamoto H. Spontaneous Endometriosis in a Mandrill (Mandrillus sphinx). Journal of Comparative Pathology2012. p. 386-90.

133. Berkley KJ, Dmitrieva N, Curtis KS, Papka RE. Innervation of ectopic endometrium in a rat model of endometriosis. Proceedings of the National Academy of Sciences. 2004;101(30):11094-8.

134. Coudyzer P, Lemoine P, Jordan BF, Gallez B, Galant C, Nisolle M, et al. Hypoxia is not required for human endometrial breakdown or repair in a xenograft model of menstruation. The FASEB Journal. 2013;27(9):3711-9.

135. Appleyard CB, Cruz ML, Rivera E, Hernández GA, Flores I. Experimental endometriosis in the rat is correlated with colonic motor function alterations but not with bacterial load. Reproductive Sciences. 2007;14(8):815-24.

136. Becker CM, Wright RD, Satchi-Fainaro R, Funakoshi T, Folkman J, Kung AL, et al. A novel noninvasive model of endometriosis for monitoring the efficacy of antiangiogenic therapy. The American journal of pathology. 2006;168(6):2074-84.

137. Pelch KE, Sharpe-Timms KL, Nagel SC. Mouse model of surgically-induced endometriosis by auto-transplantation of uterine tissue. JoVE (Journal of Visualized Experiments). 2012(59):e3396.

138. Bruner KL, Eisenberg E, Gorstein F, Osteen KG. Progesterone and transforming growth factor- $\beta$ coordinately regulate suppression of endometrial matrix metalloproteinases in a model of experimental endometriosis. Steroids. 1999;64(9):648-53.

139. Fazleabas AT, Brudney A, Gurates B, Chai D, Bulun S. A modified baboon model for endometriosis. Annals of the New York Academy of Sciences. 2002;955(1):308-17.

140. Cummings AM, Metcalf JL. Induction of endometriosis in mice: A new model sensitive to estrogen. Reproductive Toxicology1995. p. 233-8.

141. Defrère $S$, Van Langendonckt $A$, Ramos RG, Jouret M, Mettlen M, Donnez J. Quantification of endometriotic lesions in a murine model by fluorimetric and morphometric analyses. Human Reproduction. 2006;21(3):810-7.

142. Lebovic DI, Kir M, Casey CL. Peroxisome proliferator-activated receptor-gamma induces regression of endometrial explants in a rat model of endometriosis. Fertility and sterility. 2004;82:1008-13.

143. Uygur D, Aytan H, Zetgeroglu S, Batioglu S. Leflunomide-an immunomodulator-induces regression of endometrial explants in a rat model of endometriosis. The Journal of the Society for Gynecologic Investigation: JSGI. 2006;13(5):378-83.

144. Güney M, Oral B, Karahan N, Mungan T. Regression of endometrial explants in a rat model of endometriosis treated with melatonin. Fertility and sterility. 2008;89(4):934-42.

145. Cotroneo MS, Lamartiniere CA. Pharmacologic, but not dietary, genistein supports endometriosis in a rat model. Toxicol Sci. 2001;61(1):68-75.

\section{Tables}


Table 1

Comparison of new proposed methods of endometriosis induction for hormone related studies

\begin{tabular}{|c|c|c|c|c|c|c|c|c|c|}
\hline & Species & $\begin{array}{l}\text { Induction } \\
\text { method }\end{array}$ & $\begin{array}{l}\text { pharmacological } \\
\text { effects }\end{array}$ & $\begin{array}{l}\text { Relevant } \\
\text { life } \\
\text { stage }\end{array}$ & $\begin{array}{l}\text { Hormonal } \\
\text { evaluation }\end{array}$ & $\begin{array}{l}\text { Genetic } \\
\text { evaluation }\end{array}$ & $\begin{array}{l}\text { Histological } \\
\text { evaluation }\end{array}$ & Total & Reference \\
\hline $\begin{array}{l}\text { Optimal } \\
\text { animal model }\end{array}$ & 2 & 3 & 1 & 1 & 2 & 2 & 1 & 12 & \\
\hline $\begin{array}{l}5.1 .1 \text {. } \\
\text { Steroidogenic } \\
\text { factor } 1 \text { and } \\
\text { endometriosis }\end{array}$ & 1 & 1 & 0 & $\begin{array}{l}-1 \\
\text { (6-8 } \\
\text { weeks } \\
\text { old) }\end{array}$ & 0 & 0 & 1 & 2 & (52) \\
\hline $\begin{array}{l}5.1 .2 \text {. } \\
\text { Estrogen } \\
\text { receptor } \beta \text { and } \\
\text { endometriosis }\end{array}$ & 1 & 1 & 0 & $\begin{array}{l}-1 \\
\text { (5 } \\
\text { weeks } \\
\text { old) }\end{array}$ & 1 & 0 & 1 & 3 & (94) \\
\hline $\begin{array}{l}\text { 5.1.3. } \\
\text { Activated AKT } \\
\text { pathway } \\
\text { promotes } \\
\text { establishment } \\
\text { of } \\
\text { endometriosis }\end{array}$ & 1 & 1 & 1 & $\begin{array}{l}-1 \\
\text { (6 } \\
\text { weeks } \\
\text { old) }\end{array}$ & 1 & 0 & 1 & 4 & (97) \\
\hline $\begin{array}{l}5.2 .1 . \\
\text { Immortalized } \\
\text { human } \\
\text { eutopic } \\
\text { endometrial } \\
\text { stromal cells } \\
\text { line for } \\
\text { endometriosis } \\
\text { study }\end{array}$ & 1 & 2 & 0 & $\begin{array}{l}-1 \\
\text { (5-8 } \\
\text { weeks } \\
\text { old) }\end{array}$ & 0 & 0 & 0 & 2 & (101) \\
\hline $\begin{array}{l}\text { 5.3.1. } \\
\text { Estrogen } \\
\text { Receptor } \\
\text { Signaling and } \\
\text { endometriosis }\end{array}$ & 1 & 1 & 0 & $\begin{array}{l}1 \\
\text { (Adult) }\end{array}$ & 2 & 1 & 1 & 7 & $\begin{array}{l}(104) \\
105)\end{array}$ \\
\hline $\begin{array}{l}\text { 5.3.2. Mouse } \\
\text { model of } \\
\text { ovarian } \\
\text { endometriosis }\end{array}$ & 1 & 1 & 0 & $\begin{array}{l}1 \\
\text { (9 } \\
\text { weeks } \\
\text { old ) }\end{array}$ & 1 & 1 & 1 & 6 & (106) \\
\hline $\begin{array}{l}\text { 5.3.3. A high } \\
\text { mimicking } \\
\text { mouse model } \\
\text { of } \\
\text { endometriosis }\end{array}$ & 1 & 1 & 0 & $\begin{array}{l}1 \\
(11 \\
\text { weeks } \\
\text { old) }\end{array}$ & 2 & 1 & 1 & 7 & (90) \\
\hline
\end{tabular}

Scoring for each study is considered as follows:

Species: Non-human primate $=2$, Non-human mammal $=1$

Induction method: spontaneous disease occurrence $=3$, xenotransplantation $=2$, autotransplantation $/$ allotransplantation $=1$

pharmacological effects: Consistent drug effects with human $=+1$, No pharmacological evaluation $=0$, Non-consistent drug effects with human $=-1$

Relevant life stage: Identical life stage $=+1$, Not mentioned $=0$, Non-identical life stage $=-1$

Hormonal evaluation: More than one similar hormonal marker regulation to human $=+2$, Single marker regulation similarity to human $=$ +1 , Not mentioned $=0$, Non-consistent hormonal marker(s) regulation(s) with human $=-1$

Genetic evaluation: More than one similar gene expression with human $=+2$, Single gene expression similarity with human $=+1$, No genetic evaluation $=0$, Non-consistent gene(s) regulation(s) with human $=-1$

Histological evaluation: Ectopic lesion(s) detection $=+1$, Not mentioned = 0, No ectopic lesion(s) detection $=-1$ 


\begin{tabular}{|c|c|c|c|c|c|c|c|c|c|}
\hline & Species & $\begin{array}{l}\text { Induction } \\
\text { method }\end{array}$ & $\begin{array}{l}\text { pharmacological } \\
\text { effects }\end{array}$ & $\begin{array}{l}\text { Relevant } \\
\text { life } \\
\text { stage }\end{array}$ & $\begin{array}{l}\text { Hormonal } \\
\text { evaluation }\end{array}$ & $\begin{array}{l}\text { Genetic } \\
\text { evaluation }\end{array}$ & $\begin{array}{l}\text { Histological } \\
\text { evaluation }\end{array}$ & Total & Reference \\
\hline $\begin{array}{l}\text { 5.3.4. } \\
\text { Bazedoxifene } \\
\text { and } \\
\text { endometriosis }\end{array}$ & 1 & 1 & 0 & 1 & 2 & 0 & 1 & 6 & $\begin{array}{l}(108) \\
109)\end{array}$ \\
\hline
\end{tabular}

$(9$

weeks

old )

Scoring for each study is considered as follows:

Species: Non-human primate $=2$, Non-human mammal $=1$

Induction method: spontaneous disease occurrence $=3$, xenotransplantation $=2$, autotransplantation $/$ allotransplantation $=1$

pharmacological effects: Consistent drug effects with human $=+1$, No pharmacological evaluation $=0$, Non-consistent drug effects with human $=-1$

Relevant life stage: Identical life stage $=+1$, Not mentioned $=0$, Non-identical life stage $=-1$

Hormonal evaluation: More than one similar hormonal marker regulation to human $=+2$, Single marker regulation similarity to human $=$ +1 , Not mentioned $=0$, Non-consistent hormonal marker(s) regulation(s) with human $=-1$

Genetic evaluation: More than one similar gene expression with human $=+2$, Single gene expression similarity with human $=+1$, No genetic evaluation $=0$, Non-consistent gene(s) regulation(s) with human $=-1$

Histological evaluation: Ectopic lesion(s) detection $=+1$, Not mentioned $=0$, No ectopic lesion(s) detection $=-1$ 


\begin{tabular}{|c|c|c|c|c|c|c|c|c|c|}
\hline & Species & $\begin{array}{l}\text { Induction } \\
\text { method }\end{array}$ & $\begin{array}{l}\text { pharmacological } \\
\text { effects }\end{array}$ & $\begin{array}{l}\text { Relevant } \\
\text { life } \\
\text { stage }\end{array}$ & $\begin{array}{l}\text { Hormonal } \\
\text { evaluation }\end{array}$ & $\begin{array}{l}\text { Genetic } \\
\text { evaluation }\end{array}$ & $\begin{array}{l}\text { Histological } \\
\text { evaluation }\end{array}$ & Total & Reference \\
\hline $\begin{array}{l}5.4 .1 . \\
\text { Spontaneous } \\
\text { endometriosis } \\
\text { in a Mandrill }\end{array}$ & 2 & 3 & 1 & $\begin{array}{l}1 \\
\text { (Adult) }\end{array}$ & 0 & 0 & 1 & 8 & $(132)$ \\
\hline $\begin{array}{l}5.4 .2 \text {. } \\
\text { Spontaneous } \\
\text { endometriosis } \\
\text { in an Rhesus } \\
\text { Macaque }\end{array}$ & 2 & 3 & 1 & $\begin{array}{l}1 \\
\text { (Adult) }\end{array}$ & 0 & 0 & 1 & 8 & (114) \\
\hline $\begin{array}{l}5.4 .3 \text {. } \\
\text { Endometriosis } \\
\text { induced by } \\
\text { unopposed } \\
\text { estrogenicity }\end{array}$ & 2 & 3 & 1 & $\begin{array}{l}1 \\
(6-10 \\
\text { year } \\
\text { old) }\end{array}$ & 2 & 0 & 1 & 10 & $(115)$ \\
\hline \multicolumn{10}{|c|}{ Scoring for each study is considered as follows: } \\
\hline \multicolumn{10}{|c|}{ Species: Non-human primate $=2$, Non-human mammal $=1$} \\
\hline \multicolumn{10}{|c|}{ Induction method: spontaneous disease occurrence $=3$, xenotransplantation $=2$, autotransplantation $/$ allotransplantation $=1$} \\
\hline \multicolumn{10}{|c|}{$\begin{array}{l}\text { pharmacological effects: Consistent drug effects with human }=+1 \text {, No pharmacological evaluation }=0 \text {, Non-consistent drug effects } \\
\text { with human }=-1\end{array}$} \\
\hline \multicolumn{10}{|c|}{ Relevant life stage: Identical life stage $=+1$, Not mentioned $=0$, Non-identical life stage $=-1$} \\
\hline \multicolumn{10}{|c|}{$\begin{array}{l}\text { Hormonal evaluation: More than one similar hormonal marker regulation to human }=+2 \text {, Single marker regulation similarity to human }= \\
+1 \text {, Not mentioned }=0 \text {, Non-consistent hormonal marker(s) regulation(s) with human }=-1\end{array}$} \\
\hline \multicolumn{10}{|c|}{$\begin{array}{l}\text { Genetic evaluation: More than one similar gene expression with human }=+2 \text {, Single gene expression similarity with human }=+1 \text {, No } \\
\text { genetic evaluation }=0 \text {, Non-consistent gene }(s) \text { regulation(s) with human }=-1\end{array}$} \\
\hline
\end{tabular}

Note: Table 1 can be placed at the end of section 5. 
Table 2

Non-novel animal models used by published studies in section 4.

\begin{tabular}{|c|c|c|c|}
\hline \# & Study section and number & Reference & $\begin{array}{l}\text { Source of utilized } \\
\text { method }\end{array}$ \\
\hline 1 & 4.1.1.1. Puerarin and endometriosis & $(16)$ & $(133)$ \\
\hline 2 & 4.1.1.2. Xenografting of human tissue supplemented with estrogen and progesterone & $(17)$ & $(134)$ \\
\hline 3 & 4.1.1.3. Cisplatin and letrozole effect on rat model of endometriosis & $(22)$ & $(87)$ \\
\hline 4 & $\begin{array}{l}\text { 4.1.1.4. Telocytes damage in endometriosis-affected rat oviduct and potential impact on } \\
\text { fertility }\end{array}$ & $(26)$ & $(86,135)$ \\
\hline 5 & 4.1.1.5. Niclosamide and endometriosis & $(28)$ & $(89) \star$ \\
\hline 6 & 4.1.1.6. Neuroangiogenesis and endometriosis & (31) & $(90)$ \\
\hline 7 & 4.1.1.7. Macrophage-nerve cross talk and endometriosis & $(32)$ & $(90)$ \\
\hline 8 & 4.1.1.8. Simvastatin and endometriosis & (35) & $(88) !$ \\
\hline 9 & 4.1.1.9. Chloroindazole (CLI), oxabicycloheptene sulfonate (OBHS) and endometriosis & (38) & $(108,136)$ \\
\hline 10 & 4.1.2.1. Levonorgestrel loaded microspheres for the treatment of endometriosis & $(45)$ & $(86)$ \\
\hline 11 & 4.2.2. Non-GnRH hormone related endometriosis articles & $(49)$ & $(86)$ \\
\hline 12 & 4.1.3.1. Dysregulations of steroid estrogen receptors and endometriosis & $(51)$ & $(137)$ \\
\hline 13 & $\begin{array}{l}\text { 4.1.3.2. Endometrial expression of steroidogenic factor } 1 \text { promotes cystic glandular } \\
\text { morphogenesis }\end{array}$ & $(52)$ & $(64)^{\star}$ \\
\hline 14 & 4.1.3.3. Niclosamide as a potential nonsteroidal therapy for endometriosis & $\begin{array}{l}\text { (Prather et } \\
\text { al. 2016) }\end{array}$ & (89) \\
\hline 15 & $\begin{array}{l}\text { 4.1.3.4. C-Jun NH2-terminal kinase (JNK) inhibitor (JNKI) bentamapimod and } \\
\text { endometriosis }\end{array}$ & $(54)$ & $(138)$ \\
\hline 16 & 4.1.3.5. High-fat diet promotion of endometriosis in an immunocompetent mouse model & $(58)$ & $(91) !$ \\
\hline 17 & $\begin{array}{l}\text { 4.1.3.6. Extracellular matrix metalloproteinase inducer expression in the baboon } \\
\text { endometrium: Menstrual cycle and endometriosis }\end{array}$ & $(62)$ & $(88,139)$ \\
\hline 18 & $\begin{array}{l}\text { 4.1.3.7. A new isoform of steroid receptor coactivator- } 1 \text { is crucial for pathogenic } \\
\text { progression of endometriosis }\end{array}$ & $(64)$ & $(140)$ \\
\hline 19 & 4.1.3.8. Krüppel-like factor 9 (KLF9) deficiency and endometriosis & $(68)$ & $(91) !$ \\
\hline 20 & 4.1.3.9. Steroid sulfatase and endometriosis & $(70)$ & $(141)$ \\
\hline 21 & 4.1.3.10. Cisplatin, letrozole and endometriosis & $(22)$ & $(87)$ \\
\hline 22 & 4.1.3.11. Bentamapimod induces regression of endometriotic lesions & (53) & (88)! \\
\hline 23 & $\begin{array}{l}\text { 4.1.3.12. Ferulic acid (FA), ligustrazine (LZ) and tetrahydropalmatine (THP) and } \\
\text { endometriosis }\end{array}$ & $(77)$ & $(86)$ \\
\hline 24 & 4.1.3.13. Lipoxin A4 (LXA4) and endometriosis & $(80)$ & $(86) \star$ \\
\hline 25 & 4.2.1.1. SKI2670 and endometriosis & $(82)$ & $(86)$ \\
\hline 26 & 4.2.2.1. Melatonin and endometriosis & $(73,83,84)$ & $\begin{array}{l}(86,142,143),(73, \\
144),(86)\end{array}$ \\
\hline 27 & 4.2.2.2. Human chorionic gonadotropin (HCG) and endometriosis & $(85)$ & $(145)$ \\
\hline
\end{tabular}

Note: Table 2 can be placed at the end of section 4 .

\section{Figures}


Figure 1

Infographic of novel endometriosis induction methods

Page 24/24 